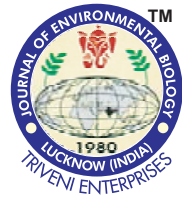

DOI : http://doi.org/10.22438/jeb/39/2/MRN-346

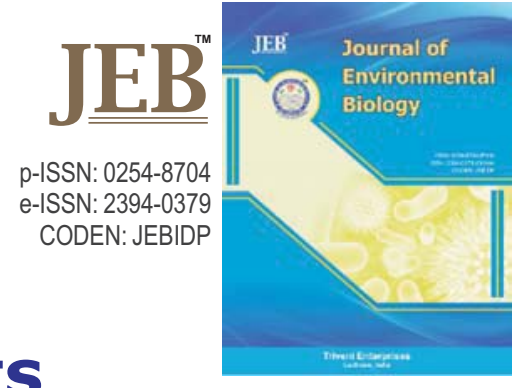

\title{
Role of biochemical constituents and minerals against cotton leaf curl disease in cotton
}

\section{Authors Info}

S. Mandhania* ${ }^{\star 1}$ R.S. Sangwan', S.S. Siwach', S.R. Pundir', O. Sangwan ${ }^{1}$ and A. Janu ${ }^{3}$ ${ }^{1}$ Cotton Section, Department of Genetics and Plant Breeding, Chaudhary Charan Singh Haryana Agricultural University, Hisar-125 001, India

${ }^{2}$ Directorate of Research, Chaudhary Charan Singh Haryana Agricultural University, Hisar-125 001, India

${ }^{3}$ Department of Entomology, Chaudhary Charan Singh Haryana Agricultural University, Hisar-125 001, India

${ }^{*}$ Corresponding Author Email : smbiochem@gmail.com

Key words

Cotton genotype

Leaf curl disease

Phenols

Polymerase chain reaction

Viral infection

\section{Publication Info}

Paper received : 10.05.2016

Revised received : 22.11.2016

Re-revised received : 20.05.2017

Accepted : 24.06.2017

\begin{abstract}
\end{abstract}
Aim : Cotton Leaf Curl Disease (CLCUD) is among the most devastating disease infecting the cotton plants. The plants have developed both inherent, consecutive and induced defence mechanism against the disease like pre-existing physical and chemical barriers, such as inducible defence responses that interfere with pathogen establishment. Therefore, the present study was conducted to examine the status of biochemical constituents and minerals with their imparting defensive role against CLCUD.

Methodology : The four cotton genotypes H 1478, H 1098i, H 1156 and $\mathrm{H} 1463$ were screened for cotton leaf curl disease on the consecutive and induced defensive role basis of polyphenoloxidase, peroxidase, biochemical constituents and minerals. The genotypes were grown under field condition at Cotton Research Farm, Chaudhary Charan Singh Haryana Agricultural University, Hisar. Leaf samples of healthy and diseased cotton plants were collected and analyzed for biochemical constituents, minerals and enzymes activities.

Results : The amount of phenol, gossypol and soluble protein were significantly higher in healthy plant as compared to diseased plant in all genotypes, whereas sugar content differed non-significantly and inconsistently among the genotypes. The polyphenoloxidase and peroxidase activities were also found significantly higher in healthy plant in all genotypes and correlate with high amount of phenolic compounds. Potassium, manganese, zinc and sulphur were significantly less in diseased plant of all genotypes. Inconsistent pattern was observed among genotypes in response to CLCuD for copper content. It differed significantly between healthy and diseased plants only in H 1156 and $\mathrm{H} 1463$ genotypes.

Interpretation : The high content of potassium, manganese, sulphur and phenolic compounds in healthy plant of $\mathrm{H}$ 1463 genotypes leads to path for plant protection by means of their direct and indirect role against plant pathogen.

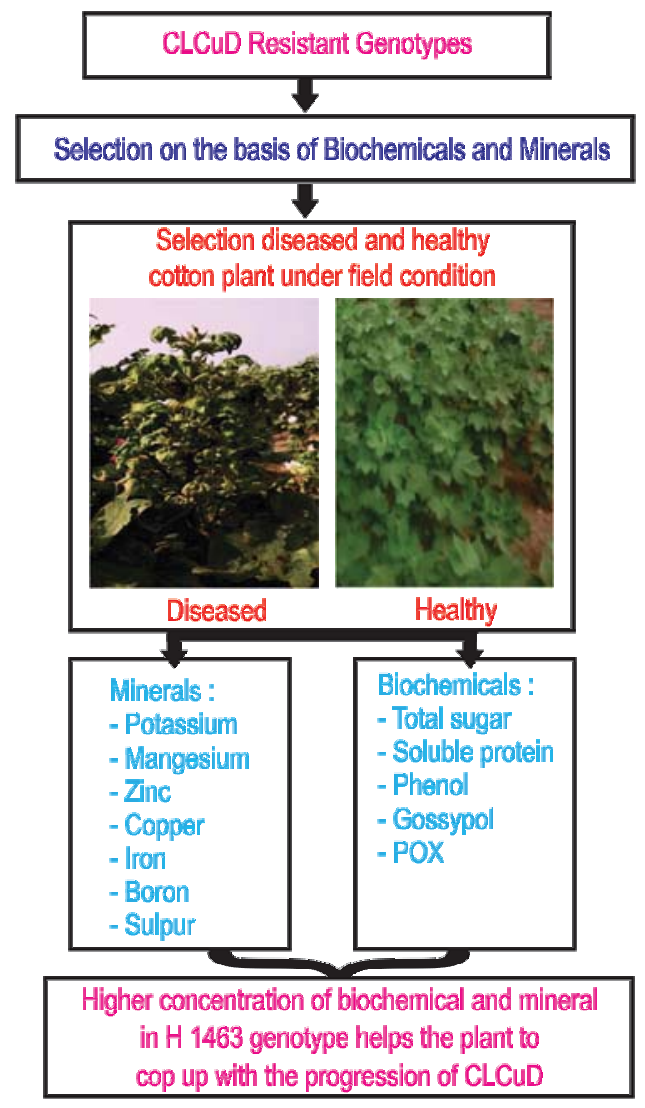




\section{Introduction}

Leaf curl is one of the most common and destructive disease of upland cotton in Indian subcontinent, presently restricted to northern cotton growing areas of around 15 lakh ha in Haryana, Punjab and Rajasthan. The disease was first reported in India on Gossypium barbadense at Indian Agricultural Research Institute, New Delhi in 1989, subsequently it appeared in patches during 1993 around Sriganganagar district of Rajasthan and Ferozpur district of Punjab adjoining to Pakistan border on $G$. hirsutum and spread to entire north India in a short span of 4-5 years (Monga, 2014). The disease is caused by a complex of monopartite begomoviruses and a small symptom modulating, single stranded satellite DNA, $\beta$ component transmitted by whitefly Bemisia tabaci (Akhtar et al., 2013). The begomovirus beta satellite complexes that cause cotton leaf curl disease in Asia and Africa continent are distinct. The complex reported in India and Pakistan during the 1990s consisted of multiple begomovirus species (often occurring as multiple infections more than one virus per plant) supporting a disease-specific beta satellite, as well as an alpha satellite (Tahir et al., 2011). Till date, at least nine begomovirus species (CLCuVs) infecting cotton have been reported in Indian subcontinent. Cotton leaf curl burewala virus (CLCuBuV) infected plants are usually stunted and bushy. Younger leaves of infected plants can show downward cupping, followed by either upward or downward curling of leaf margins, swelling and darkening of veins, which frequently develop into cup shaped and leaf like out growths called 'enations'. Leaves from infected plants become thickened and more brittle than those from healthy plants. Severely infected leaves can show rolling and a reduction in size followed by malformation of leaf petioles, branches and main stem (Akhtar et al., 2008). The use of resistant varieties is the safest, economical and effective option to manage, but unfortunately introgressed host plant resistant was rapidly overcome by the resistant breeding strain of CLCuBuV during 2005 and all the available cultivated genotypes from $\mathrm{G}$. hirsutum are susceptible (Akhtar et al., 2010).

The development of more CLCuD-resistant cotton is necessary to alleviate future threats to cotton in Indian subcontinent. Disease resistance in plants is associated with activation of a wide array of defence responses that slow down or halt infection at certain stages of the host-pathogen interaction. Plants have evolved various pre-existing physical and chemical barriers (Mandhania et al., 2015), such as inducible defence responses that interfere with pathogen establishment (Jones and Dangl, 2006; Zhao et al., 2008; Vanitha et al., 2009). The exact status regarding the response of $\mathrm{CLCuV}$ to biochemical constituents and minerals of cotton plant is not clear, which is the dire need of present situation. With this background, the present study was carried out to gain more information on the possible changes of biochemical constituents and minerals during systemic virus infection in healthy plants of cotton genotypes.

\section{Materials and Methods}

Four cotton genotypes, H 1478, H 1098i, H 1156 and H 1463 with CLCuV diseased and healthy plants were selected, grown in research field area, Cotton Section, Department of Genetics and Plant Breeding during year 2013-14. The leaves samples were collected from fourth leaf from top on the main stem. The presence of CLCuV was confirmed after isolation of total genomic DNA from these leaves by cetyl trimethylammonium bromide (CTAB) method (Doyle and Doyle, 1990) and subjected to PCR for the amplification of cotton leaf curl virus using specific primers (Briddon et al., 2002; Amrao et al., 2010).

Dried crushed (500 mg) leaf samples were mixed with 30 $\mathrm{ml} 80 \%$ ( $\mathrm{v} / \mathrm{v}$ ) hot ethanol and centrifuged at $7000 \mathrm{rpm}$ for $10 \mathrm{~min}$ and the supernatant were collected. Total soluble sugar content was determined following the method of phenol sulphuric acid (Dubois, 1956), total phenolic compounds were determined by Folin-Ciocalten's calorimetric method (Bray and Thorpe, 1954) and gossypol was estimated by pholesoglucinol reagent (Bell, 1967). For protein estimation, $500 \mathrm{mg}$ leaves were ground in cold extraction buffer and samples was centrifuged at $15,000 \times \mathrm{g}$ for 10 min at $4^{\circ} \mathrm{C}$, supernatant was separated and measured by dye binding assay, as described by Bradford (1976).

Polyphenoloxidase activity was measured according to the method described by Ying and Zhang (2008). The enzyme activity was determined spectrophotometrically using catechol as substrate. The changes in absorbance at $420 \mathrm{~nm}$ for $5 \mathrm{~min}$ was measured with UV-VIS spectrophotometer. One unit of polyphenoloxidase activity was defined as the amount of enzyme that produces one $\mu \mathrm{mol}$ of o-dopaquinone per minute.

Peroxidase activity was assayed following the method of Shannon et. al. (1966) with minor modification. The leaves were homogenized in a medium containing of $0.1 \mathrm{M}$ Tris $\mathrm{HCl}$ buffer $(\mathrm{pH}$ 7.6), $0.1 \mathrm{M}$ EDTA. The assay solution ( $4 \mathrm{ml}$ ) contained $3.620 \mathrm{ml}$ of $0.1 \mathrm{M}$ phosphate buffer ( $\mathrm{pH} 7.0), 0.2 \mathrm{~mL} 0.1 \%$ O-dianisidine, 0.1 $\mathrm{ml}$ of $0.2 \% \mathrm{H}_{2} \mathrm{O}_{2}$ and $0.08 \mathrm{ml}$ enzyme extract. The reaction was initiated by adding $\mathrm{H}_{2} \mathrm{O}_{2}$. The increase in absorbance was recorded after every minute. One unit POX activity was defined as the amount of enzyme that produce one $\mu \mathrm{mol}$ of product per minute.

Heavy metals like manganese, zinc, copper, boron and sulphur in leaf samples were estimated with an atomic absorption spectrometer Analyst 100 (Perkin Elmer, Beaconsfield, Germany), wherever potassium content was determined with a flame photometer (Elico CL 378, India). Statistical analyses were performed by two-way analysis of variance (ANOVA) using OP STAT (online version) and comparison between the mean values were made by least significant difference at 0.05 probability level. 


\section{Results and Discussion}

Total phenol, gossypol and protein content differed significantly between healthy and diseased cotton plants. The activity of peroxidase enzyme in all genotypes was significantly higher in healthy plant, whereas healthy plant of $\mathrm{H} 1478$ (1.13 $\mu \mathrm{mol} \mathrm{g}^{-1}$ f. wt.) and $\mathrm{H}$ 1098i (1.17 $\mu \mathrm{mol} \mathrm{g}^{-1} \mathrm{f}$. wt.) did not show significant differences to respective diseased plant 1.12 and 1.12 $\mu \mathrm{mol} \mathrm{g}^{-1} \mathrm{f}$. wt. for polyphenoloxidase enzyme. The higher level of these biochemical constituent particularly phenol and gossypol may contribute towards the defence of plant against viral disease. Siddique et al. (2014) and Rohini et al. (2011) reported higher accumulation of phenolic compound after infection. The highest phenol (Fig. 1a) and gossypol (Fig. 1b) content (1.40 and 0.48\%) was found in healthy plants of $\mathrm{H} 1478$ genotype, followed by $\mathrm{H}$ 1463 genotype. Similar results was reported by Markakis et al. (2010) who observed negative association between phenolic compound and Verticillium dahlia, pathogen of Verticillium wilt in olive tree. These results are in line with the results reported on other plant-pathogenic fungal, bacterial and viral interactions, which showed that certain common phenols and phenolic substances are toxic to pathogens, which have long been considered as important defence related compounds whose levels are naturally high in the resistant varieties of many crops (Gogoi et al., 2001) and accumulate in plants after infection, especially in resistant varieties (Agrios, 1997; Rohni et al., 2011).

The results in Fig.1c represent inconsistent and nonsignificant sugar content in healthy and diseased plant. Healthy plant of $\mathrm{H} 1478$ genotype contained high amount of sugar $(6.26 \%)$, whereas least sugar $(2.14 \%)$ was observed in healthy plants of $\mathrm{H} 1463$ genotype. Higher content of sugar contribute towards higher rate of infection. Higher disease incidence in high sugar containing genotypes as well as less content of phenolic compounds was also reported by Abdullah and Singh (2004) and Mandhania et al. (2016) in cotton genotypes. Involvement of protein components in plant disease resistance has been documented in many plant pathogenic interactions (Tornero et al., 2002; Carvalho et al., 2006). Significant difference was observed for soluble protein among healthy and diseased plant leaves, but within genotypes it was non-significant (Fig. 1d). In the present study, protein content was found to decreas significantly in CLCuV-infected plants. A possible explanation for significant decrease in total soluble protein contents in CLCuV diseased plants may be due to poor upregulation of plant defence mechanism. Similar results have been reported in maize, tomato, grapevine, and apple infected with mollicutes (Musetti, 2010).

Significantly higher peroxidase (Fig.1e) and polyphenoloxidase (Fig. 1f) activities (13.02 and $1.36 \mu \mathrm{mol} \mathrm{g}^{-1} \mathrm{f}$. wt.) were also found higher in $\mathrm{H} 1463$ and $\mathrm{H} 1156$ genotypes (12.95 and $1.34 \mu \mathrm{mol} \mathrm{g}^{-1} \mathrm{f}$. wt.), respectively. The enzymes peroxidase and polyphenoloxidase play an important role in plant protection against the disease incidence by involving in the lignifications, wound healing, regulation of cell wall, oxidation of phenolic to more free radicals that can react with biological molecules, thus creating an unfavourable environment for pathogen development (Maksinov et al., 2014; Mohamed et al., 2012). Similar results were reported in tomato infected with tomato mosaic tobamovirus (Madhusudan et al., 2009) and cucumber infected with cucumber mosaic virus (Riedle-Bauer, 2000). Significantly higher enzyme activity of polyphenoloxidase and phenylalanine ammonia lyase as well as higher concentrations of chlorogenic acid and total soluble phenols in potato was studied by Ngadze et al. (2012) upon inoculation with bacterial suspension. The resistance in varieties was correlated with high polyphenoloxidase and phenylalanine ammonia lyase enzyme activity, as well as increased concentrations of chlorogenic acid and total soluble phenols.

The incidence of disease attack leads to accumulation and depletion of different nutrients in both healthy and diseased plant leaves. Potassium, sulphur, zinc and manganese content were found significantly more in healthy plant leaves as compared to infected plant leaves. A considerably lower concentration of potassium in diseased leaves of all genotypes, laid out in Fig. 2a, can be explained by the fact that potassium is mobile nutrient (Mangel and Kirkby, 1987; Marschner, 1995) and under normal condition it readily moves from older to younger leaves through phloem. Since infected leaves of all genotypes were severely affected and curled and occurrence of substantial/ partial blockage of vascular system of these leaves may hamper the flow of potassium. It has also been reported in scanning electron microscope studies by lqbal et al. (2006). In contrast, the healthy plant leaves were not curled and normal, thus almost maintained the potassium state. Diseased plants had lesser manganese and sulphur content. Fig. $2 b$ shows that the manganese content decreased upto $40 \%$ in three genotypes, except $\mathrm{H}$ 1098i genotype where it showed maximum decrease $(15.83 \%)$ in sulphur content (Fig. 2d). Healthy plant leaves was found to contain non-significantly lesser boron (Fig. 2e) content as compared to diseased plant leaves. As shown in Fig. 2c, inconsistent pattern was observed among the genotypes in response to CLCuD for copper content and it differed significantly between healthy and diseased plants only in $\mathrm{H} 1156$ and $\mathrm{H} 1463$ genotypes. The role of manganese, copper and zinc is poorly understood. The high amount of these nutrient in healthier plant may contribute their role toward provide tolerance against cell wall integrity. Copper and manganese particularly play an important function in the activation of metabolic synthesis of lignin (Porcheron et al., 2013), and thus in controlling pathogen. Manganese also contribute important role in establishment of pathogen resistant by inhibiting cell wall degrading enzyme (Dordas, 2008).

Significantly reduced zinc content was observed in diseased plant leaves of all genotypes than healthy plant leaves (Fig. 2f). Reduced zinc content leads to lesser green plant hence 


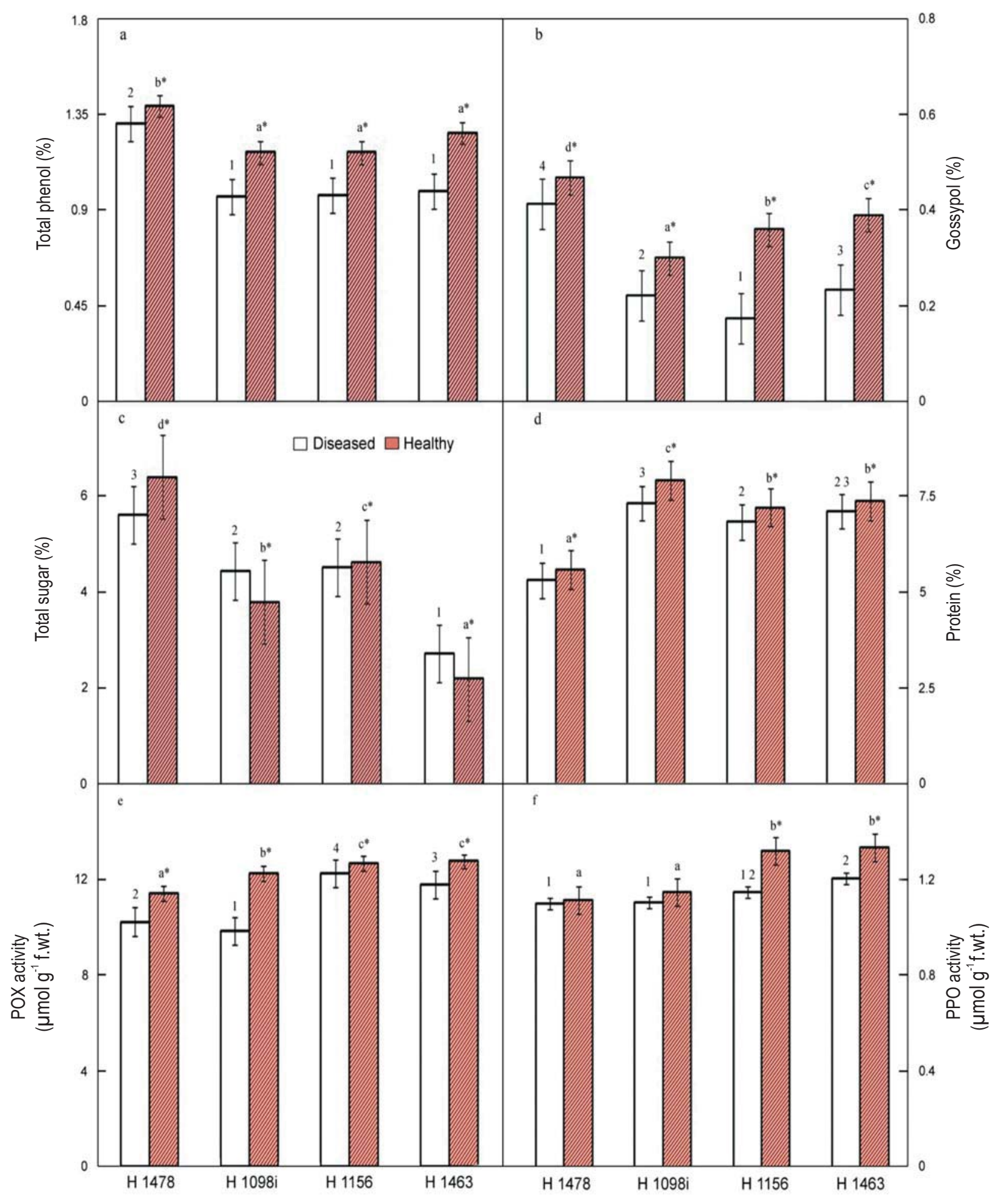

Fig. 1: Percentage values of (a) Total phenol (b) Total gossypol (c) Total sugar (d) Total soluble protein (e) Peroxidase activity (f) Polyphenoloxidase activity in healthy and respective diseased plants leaves; Figures followed by same alphabet and same numeric do not differ statistically; Figures followed by ${ }^{*}$ differ statistically within genotype 


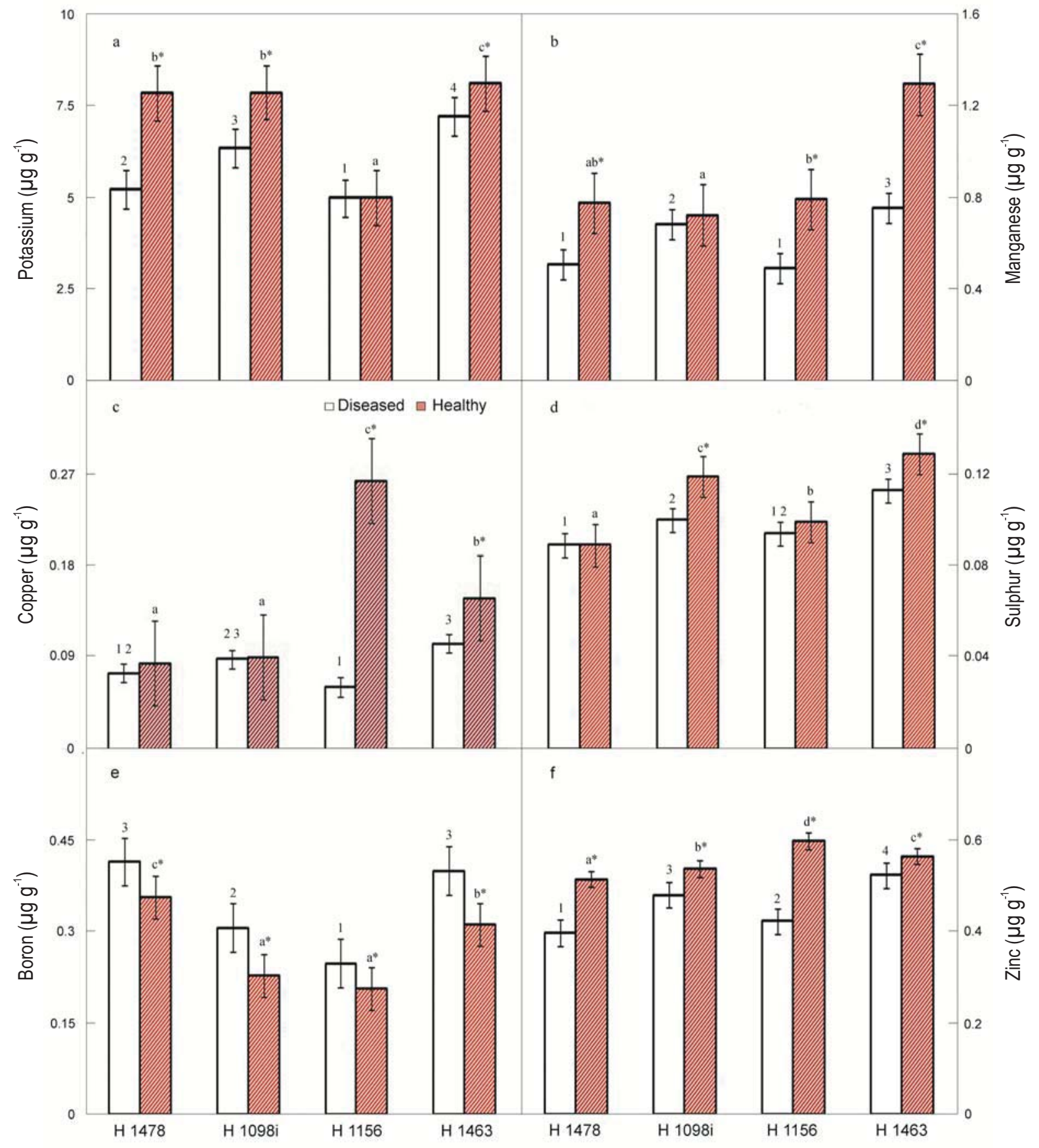

Fig. 1: Microgram per gram values of (a) Potassium (b) Manganese (c) Copper (d) Sulphur (e) Boron (f) Zinc content in healthy and respective diseased plant leaves; Figures followed by same alphabet and same numeric do not differ statistically; Figures followed by * differ statistically within genotype

had lesser chlorophyll content (Data not shown). The possible explanation is that zinc is an immobile element in the plant tissues and directly constitutes chlorophyll. In healthy plants, zinc maintain the integrity of plasma membrane as zinc ions are known to be a strong inhibitor of NADPH oxidase resulting in lesser production of oxyradical (Pinton et al., 1994, Porcheron et al., 2013).
The elevated response of biochemical constituents and mineral content were observed among the cotton genotype as a result of CLCuV infestation. The H 1463 genotype had higher content of potassium, manganese and sulphur but low sugar content. The PPO and POX activities were also found higher in $\mathrm{H}$ 1463 genotype. The higher concentration of biochemical, mineral and pathogenesis related protein helps the plant to cope up with 
the progression of $\mathrm{CLCuD}$ in $\mathrm{H} 1463$ genotype.

\section{Acknowledgment}

The article was written with support from Indian Council of Agricultural Research (ICAR), India.

\section{References}

Abdullah, N.M.M. and J. Singh: Biology of whitefly, Bemisia tabaci (Gennadius) on cotton under Punjab conditions. Pest Mgt. Econ. Zool., 12, 1-6 (2004).

Agrios, G.N.: Plant Pathology. $4^{\text {th }}$ Edn., Academic Press Inc. San Diego, CA(1997).

Akhtar, K.P., S. Haidar, M.K.R. Khan, M. Ahmad, N. Sarwar, M.A. Murtaza and M. Aslam: Evaluation of Gossypium species for resistance to cotton leaf curl Burewala virus. Ann. Appl. Biol., 157, 135-147 (2010).

Akhtar, K.P., F.F. Jamil, M.A. Haq and I.A. Khan: Comparison of resistance to cotton leaf curl disease (Multan/Burewala) among Gossypium hirsutum L. varieties and breeding lines. J. Phytopathol., 156, 352-357 (2008).

Akhtar, K.P., R. Ullah, I.A Khan, M. Saeed, N. Sarwar and S. Mansoor First symptomatic evidence of infection of Gossypium arboreum with cotton leaf curl Burewala virus through grafting. Int. J. Agric. Biol., 15, 157-160 (2013).

Amrao, L., I. Amin, M.S. Shahid, R.W. Briddon and S. Mansoor : Cotton leaf curl disease in resistant cotton is associated with a single begomovirus that lacks an intact transcriptional activator protein. Virus Res., 152, 153-163 (2010).

Bell,A.A.: Formation of gossypol in infected or chemically irritated tissues of Gossypium species. Phytopathology, 57, 759-764 (1967).

Bradford, M.M.: A rapid and sensitive method for the quantitation of microgram quantities of protein utilizing the principle of protein-dye binding. Anal. Biochem., 72, 248-254 (1976).

Bray, H.G. and W.V. Thorpe: Analysis of phenolic compounds of interest in metabolism. Methods Biochem. Anal., 1, 27-52 (1954).

Briddon, R.W., S.E. Bull, S. Mansoor, I. Amin and P.G. Markham : Universal primers for the PCR-mediated amplification of DNA a molecule associated with some monopartite begomoviruses. Mol. Biotecnol., 20, 315-318 (2002).

Carvalho, D., Q. Anastacio and M. Luciana: Proteins and isozymes electrophoresis in seeds of Desti (Leguminosae caesalpinioidea) artificially aged. Rev. Arvore., 30, 19-21 (2006).

Dordes, C.: Role of nutrients in controlling plant diseases in sustainable agriculture. Areview. Agron. Sustain. Dev.. 28, 33-46 (2008)

Doyle, J.J. and J.L. Doyle: Isolation of plant DNA from fresh tissue. Focus, 12, 13-15(1990).

Dubois, M., K.A. Gilles, J.K. Hamilton, P.A. Rebers and F. Smith: Colorimetric method for determination of sugars and related substances. Anal. Chem., 28, 350-356 (1956).

Gogoi, R., D.V. Singh and K.D. Srivastava: Phenols as a biochemical basis of resistance in wheat against Karnal bunt. Plant Pathol., 50, 470-476 (2001).

Iqbal, N., M.Y. Ashraf, F. Javed, M. Ashraf and S. Hameed: Cotton leaf curl virus: ionic status of leaves and symptom development. J. Integr. Plant Biol., 48, 558-562 (2006).

Jones, J.D.G. and J.L. Dangl: The plant immune system. Nature, 444, 323-329 (2006).
Madhusudhan, K.N., B.M. Srikanta, M.D. Shylaja, H.S. Prakash and H.S. Shetty: Changes in antioxidant enzymes, hydrogen peroxide, salicylic acid and oxidative stress in compatible and incompatible host tobamovirus interaction. J. Plant Interact., 4, 157-166 (2009).

Maksimov, I., N. Troshina, O. Surina and E. Cherepanova: Salicylic acid increases the defense reaction against bunt and smut pathogens in wheat calli. J. Plant Interact., 9, 306-314 (2014).

Mandhania, S., S.R. Pundir, S.S. Siwach, R.S. Sangwan, O. Sangwan, S. Nimal and A. Jain: Nutritional quality constituents' relationship in desi (Gossypium arboreum) cotton. J. Cotton Res. Dev., 29, 87-89 (2015).

Mandhania, S., S.R. Pundir, R.S. Sangwan, K. Rolania, O. Sangwan and A. Janu: Allelochemicals studies in cotton genotypes having differential reaction of Leafhopper (Amrasca devastans). Eco. Env. Cons., 22, S195-S198 (2016).

Mangel, K. and E.A. Kirkby: Principles of plant Nutrition. $4^{\text {th }}$ Edn., International Potash Institute, Bern (1987).

Markakis, E.A., S.E. Tjamos, P.P. Antoniou, P.A. Roussos, E.J. Paplomatas and E.C. Tjamos: Phenolic responses of resistant and susceptible olive cultivars induced by defoliating and nondefoliating Verticillium dahlia pathotypes. Plant Dis., 94, 11561162 (2010).

Marschner, H.: Mineral Nutrition of higher plants. $2^{\text {nd }}$ Edn., Academic Press, London (1995).

Mohamed, H., A.A. EL-Hady, M. Mansour, El-Rheem and A. ElSamawaty: Association of oxidative stress components with resistance to flax powdery mildew. Trop. Plant Pathol., 37, 386-392 (2012).

Monga, D.: Cotton leaf curl virus disease. Technical Bulletin, Published by Director, Central Institute for Cotton Research, Nagpur, p. 34 (2014).

Musetti, R.: Biochemical changes in plants infected by phytoplasmas. In: Phytoplasmas: genomes, plant hosts, and vectors. (Eds.: P.G. Weintraub and P. Jones) Wallingford: MPG Books Group, UK (2010).

Ngadze, E., D. Icishahayo, T.A. Coutinho and J.E. van der Waals: Role of polyphenol oxidase, peroxidase, phenylalanine ammonia lyase, chlorogenic acid and total soluble phenols in resistance of potatoes to soft rot. Plant Dis., 96, 186-192 (2012).

Pinton, R., I. Cakmak and H. Marschner: Zinc deficiency enhanced $\mathrm{NAD}(\mathrm{P}) \mathrm{H}$ dependent superoxide radical production in plasma membrane vesicles isolated from roots of bean plants. J. Exp. Bot., 45, 45-50 (1994).

Porcheron , G., A. Garénaux, J. Proulx, M, Sabri and C. M. Dozois: Iron, copper, zinc, and manganese transport and regulation in pathogenic Enterobacteria: correlations between strains, site of infection and the relative importance of the different metal transport systems for virulence. Front. Cellul. Infect. Microbiol., 3, 1-24 (2013).

Riedle-Bauer, M.: Role of reactive oxygen species and antioxidant enzymes in systemic virus infections of plants. J. Phytopathol., 148, 297-302 (2000).

Rohini, A., N.V.V.S.D. Prasad, M.S.V. Chalam and K. Veeraiah: Identification of suitable resistant cotton genotypes against sucking pests. J. Ent. Res., 35, 197-202 (2011).

Shannon, L.M., E. Key and J.Y. Law: Peroxidase isozymes from horse reddish roots: Isolation and physical properties. J. Biol. Chem., 241, 2166-2172(1966). 
Siddique, Z., K.P. Akhtar, A. Hameed, S. Nighat, Imran-UI-Haq and S.A. Khan: Biochemical alterations in leaves of resistant and susceptible cotton genotypes infected systemically by cotton leaf curl Burewala virus. J. Plant Interact., 9, 702-711 (2014).

Tahir, M.N., I. Amin, R.W. Briddon and S. Mansoor: The merging of two dynasties-identification of an African cotton leaf curl diseaseassociated begomovirus with cotton in Pakistan. PLoS One, 6 , e20366 (2011).

Tornero, P., R. Chao, W. Luthin, S. Goff and J. Dangl: Largescale structure, function, analysis, of Arabidopsis RPM1 disease resistance protein. Plant Cell, 14, 435-450 (2002).

Vanitha, S.C., S.R. Niranjana and S. Umesha: Role of phenylalanine ammonia lyase and polyphenol oxidase in host resistance to bacterial wilt of tomato. J. Phytopathol., 157, 552-557 (2009).

Ying, Y. and W. Zhang: Some properties of polyphenol oxidase from lily. Int. J. Food Sci. Tech., 43, 102-107 (2008).

Zhao, C.J., A.R. Wang, Y.J. Shi, L.Q. Wang, W.D. Liu, Z.H. Wang and G.D. Lu: Identification of defense-related genes in rice responding to challenge by Rhizoctonia solani. Theor. Appl. Genet., 116, 501516 (2008). 